\title{
WHO/ISUP grading of clear cell renal cell carcinoma and papillary renal cell carcinoma; validation of grading on the digital pathology platform and perspectives on reproducibility of grade
}

Lisa Browning ${ }^{1,2^{*}}$, Richard Colling ${ }^{1,3}$ and Clare Verrill ${ }^{1,2,3}$

\begin{abstract}
Background: There are recognised potential pitfalls in digital diagnosis in urological pathology, including the grading of dysplasia. The World Health Organisation/International Society of Urological Pathology (WHO/ISUP) grading system for renal cell carcinoma (RCC) is prognostically important in clear cell RCC (CCRCC) and papillary RCC (PRCC), and is included in risk stratification scores for CCRCC, thus impacting on patient management. To date there are no systematic studies examining the concordance of WHO/ISUP grading between digital pathology (DP) and glass slide (GS) images. We present a validation study examining intraobserver agreement in WHO/ISUP grade of CCRCC and PRCC.

Methods: Fifty CCRCCS and 10 PRCCs were graded (WHO/ISUP system) by three specialist uropathologists on three separate occasions (DP once then two GS assessments; GS1 and GS2) separated by wash-out periods of at least two-weeks. The grade was recorded for each assessment, and compared using Cohen's and Fleiss's kappa.

Results: There was 65 to 78\% concordance of WHO/ISUP grading on DP and GS1. Furthermore, for the individual pathologists, the comparative kappa scores for DP versus GS1, and GS1 versus GS2, were 0.70 and $0.70,0.57$ and 0.73 , and 0.71 and 0.74 , and with no apparent tendency to upgrade or downgrade on DP versus GS. The interobserver kappa agreement was less, at 0.58 on DP and 0.45 on GS.

Conclusion: Our results demonstrate that the assessment of WHO/ISUP grade on DP is noninferior to that on GS. There is an apparent slight improvement in agreement between pathologists on RCC grade when assessed on DP, which may warrant further study.
\end{abstract}

Keywords: Validation, Renal carcinoma, ISUP, Grading, Digital pathology, Reproducibility

\footnotetext{
* Correspondence: lisa.browning@ouh.nhs.uk

'Department of Cellular Pathology, Oxford University Hospitals NHS Trust, John Radcliffe Hospital, Headley Way, OX3 9DU Oxford, UK

${ }^{2}$ NIHR Oxford Biomedical Research Centre, Oxford University Hospitals NHS Foundation Trust, Oxford, Oxfordshire, UK

Full list of author information is available at the end of the article
}

C C The Author(s). 2021 Open Access This article is licensed under a Creative Commons Attribution 4.0 International License, which permits use, sharing, adaptation, distribution and reproduction in any medium or format, as long as you give appropriate credit to the original author(s) and the source, provide a link to the Creative Commons licence, and indicate if changes were made. The images or other third party material in this article are included in the article's Creative Commons licence, unless indicated otherwise in a credit line to the material. If material is not included in the article's Creative Commons licence and your intended use is not permitted by statutory regulation or exceeds the permitted use, you will need to obtain permission directly from the copyright holder. To view a copy of this licence, visit http://creativecommons.org/licenses/by/4.0/ The Creative Commons Public Domain Dedication waiver (http://creativecommons.org/publicdomain/zero/1.0/) applies to the data made available in this article, unless otherwise stated in a credit line to the data. 


\section{Introduction}

Adoption of digital pathology (DP) into clinical diagnostic practice is still in its early stages. In our department we now scan $100 \%$ of the surgical histology slides, and the digital imaging of urological pathology cases has been routine since January 2019. The urological pathologists have undergone a validation process to facilitate safe digital reporting in the specialty, in accordance with guidance from the Royal College of Pathologists [1]. Whilst there are multiple large validation studies which provide evidence that DP is non-inferior to light microscopy diagnosis [2-10], including specifically for remote DP reporting [11-13] there remain recognised 'pitfalls' of digital diagnosis that need to be acknowledged, one of which is grading of dysplasia $[1,14]$. In urological pathology specifically, the World Health Organisation/International Society of Urological Pathology (WHO/ISUP) grading of renal cell carcinoma (RCC) digitally has been identified by one group as a feature of potential challenge [14].

The WHO/ISUP grading system is validated for use in clear cell renal cell carcinoma (CCRCC) and papillary renal cell carcinoma (PRCC), but not chromophobe renal cell carcinoma, or other renal tumour types. Grading is based upon nucleolar prominence (grades 1-3) and with grade 4 tumours showing nuclear anaplasia $+/$ giant cells, rhabdoid and/or sarcomatoid features. This system is based upon evidence that has shown that patient outcome in CCRCC and PRCC is correlated with the prominence of tumour cell nucleoli $[15,16]$. Importantly WHO/ISUP grade is of prognostic significance and is incorporated into patient risk stratification systems such as the Leibovich score [17] which can be used to predict likely progression to metastatic disease in patients with localised CCRCC, thereby influencing patient follow-up, including potential clinical trial entry.

Published primary studies specifically investigating concordance in WHO/ISUP grading of RCC between DP and glass slides (GS) are however lacking. We have therefore undertaken a study to determine the concordance of WHO/ISUP grade assigned to CCRCC and PRCC on DP and GS, which includes the baseline assessment of the intraobserver concordance of $\mathrm{WHO} /$ ISUP grading on GS. This validation study design is in accordance with guidance from the College of American Pathology and Laboratory Quality Center [18], and in line with other published validation studies [2]. Whilst not specifically a requirement for a DP validation study, we also determined the interobserver agreement on WHO/ISUP grade for these cases.

\section{Methods}

The histopathology database in our department was searched for CCRCC and PRCC cases (nephrectomy, partial nephrectomy, biopsy) reported during 2019. These cases had been scanned at $\times 40$ magnification on the Philips IntelliSite ${ }^{\bullet}$ Ultrafast Scanner as part of the routine workflow in the department for uropathology since January 2019. Consecutive cases of CCRCC and of PRCC were assessed to ensure that the digital images were of appropriate quality for diagnostic assessment; out of focus cases and those with other artefacts were excluded. From the search, 50 CCRCCs and 10 PRCCs were identified, and two $\mathrm{H} \& \mathrm{E}$ sections of tumour from each resection case were selected, with one H\&E section available for the biopsy cases. The study was registered within our centre as a clinical audit and did not require specific ethics approval.

Three specialist consultant urological pathologists, with 12,13 and 2 years' experience post-FRCPath, were invited to assess the digital images for the selected slides on their usual DP workstations. All three had experience of DP of at least one year, and therefore did not require additional DP training prior to this study. Each pathologist was independently asked to make an assessment of the overall highest WHO/ISUP grade present in the selected sections from the cases, in accordance with the published guidance on assignment of WHO/ISUP grade, and this was documented in a spreadsheet. Initially the pathologists assessed the cases on a digital screen, and then subsequently repeated the assessment on the corresponding GS following a washout period of two weeks. A second assessment of the WHO/ISUP grade on the GS was carried out following a second washout period of at least two weeks. Two weeks was the selected time interval between reads (DP or GS) in accordance with the recommendation from the guideline for validating whole slide images for diagnostic purposes in pathology, issued by the College of American Pathology and Laboratory Quality Center [18]. The pathologists were blinded to the original histology report for the cases (which was not accessed at any point in the study except during the initial search for cases), and were blind to their prior assessments (DP and GS) and to those of the other two pathologists at the time of assessing. We did not attempt to revise the ISUP grade of the tumour in the original report on the basis of this study, and this would not have been appropriate given that only representative H\&E slides had been assessed.

The WHO/ISUP grading was carried out in accordance with the published guidance [15], and this system has been routinely utilised for grading of CCRCC and PRCC by the urological pathologists in the department since 2013.

Statistical analysis on the data was carried out using a linear weighted Cohen's kappa ( ) coefficient for intraobserver comparisons (intra-rater comparisons) and Fleiss' kappa ( ) for interobserver comparisons (for all 
three pathologists). Calculations were made using standard formulae in Microsoft Excel.

\section{Results}

The WHO/ISUP grade was independently determined by three consultant uropathologists on DP and on GS for a total of 60 cases of RCC (50 CCRCC and 10 PRCC). The assessment of WHO/ISUP grade on GS was performed on two separate occasions (termed read 1 and read 2) to provide an indication of intraobserver variability on GS assessment. The results are presented in Table 1.

\section{Agreement of WHO/ISUP grading DP versus GS}

Comparing WHO/ISUP grading on DP versus GS images (read 1) for all 60 cases, intraobserver agreement for the individual pathologists was $0.70,0.57,0.71$ (Fig. 1). There was a marginal improvement in agreement for the grading of CCRCC only; 0.72, 0.58, 0.75 .

The interobserver agreement on WHO/ISUP grade for all cases was 0.58 on digital, and 0.45 on glass (read 1), with slightly greater agreement for CCRCC alone $(0.62$ versus 0.50 ).

We also looked at the grading agreement for each individual pathologist between DP and GS read 1 for each individual case, and overall this was 47/60 (78\%), 39/60 (65\%), and 46/60 (77\%) for pathologists $\mathrm{A}, \mathrm{B}$, and $\mathrm{C}$ respectively, and therefore 132/180 (73\%) overall intraobserver agreement in grade on DP vs. GS (read 1). There was very minimal improvement when limiting analysis to CCRCC alone; 40/50 (80\%), 33/50 (66\%), 40/50 (80\%). Of the 37 discrepancies in grade for CCRCC (DP grade versus GS grade for at least one pathologist), overall 17 were downgraded by one grade on GS review, and 20 were upgraded by one grade. None of the CCRCC cases were upgraded or downgraded by more than one grade. Of the 11 discrepancies in grade for PRCC (DP grade versus GS grade for at least one pathologist), overall 4 were downgraded by one grade on GS review, and 6 were upgraded by one grade. There was a single incidence of PRCC being upgraded by 2 grades on GS review (from grade 1 to 3 , Fig. 2). In none of the cases (CCRCC or PRCC) did all three pathologists change the grade on GS review.

\section{Agreement of WHO/ISUP grading GS versus GS}

Intraobserver variability on two separate GS reads was also examined to provide an indication of kappa agreement with which the DP versus GS kappa agreement could reasonably be compared (Fig. 1).

The kappa agreement for pathologists $\mathrm{A}, \mathrm{B}$ and $\mathrm{C}$ between the two GS reads was $0.70,0.73,0.74$ respectively, and for CCRCC alone it was $0.69,0.69,0.81$ respectively.
For the individual pathologists, the comparative kappa scores for DP versus GS (read 1) and GS read 1 versus GS read 2 were 0.70 and 0.70 (pathologist A), 0.57 and 0.73 (pathologist $\mathrm{B}$ ), and 0.71 and 0.74 (pathologist $\mathrm{C}$ ).

The interobserver kappa score of agreement for GS read 1 was 0.45 versus 0.49 for GS read 2 .

\section{Discussion}

Multiple validation studies have demonstrated that DP is non-inferior to GS for histopathological diagnoses, however these studies have assessed overall diagnoses of cases rather than focussing on specific areas of discrepancy. Dysplasia has been identified within multiple of the studies as being an area of challenge for DP diagnosis, which is considered to be related to rendering of nuclear detail on DP, a factor that is confounded by scanning resolution (20x versus $40 \mathrm{x}$ ) and/or compression artefacts. There is little within the published literature on validation of DP as to the precise cause of discrepancy between the assessment of nuclear detail on DP versus GS, beyond general statements that nuclear detail may be harder to appreciate on DP [2] and that the absence of facility to focus through the entire tissue section on DP (vs. GS) impacts the appreciation of nuclear chromatin [4]. A recent meta-analysis [19] noted that $57 \%$ of clinically significant discordances between DP and light microscopy were of this nature. However, it is also recognised that assessment of dysplasia/grading is a source of discrepancy between pathologists on light microscopy, which may be a confounding factor. Furthermore, DP facilitates low power viewing of slides, and therefore there is also the potential for failure at low power to detect small areas of dysplasia (or higher grade areas) for further high power assessment [14].

Validation studies to date that include urological pathology specimens (summarised in Table 2), have consistently identified dysplasia related to urothelial specimens including grading of urothelial carcinoma as a recognised pitfall, but whilst grading of dysplasia in renal carcinoma is mentioned as a potential pitfall in one paper [14] this has not been specifically documented within the larger validation studies to date [2-13], nor within a small validation study devoted to urological specimens [20].

Given this, and the clinical importance of WHO/ISUP grading in CCRCC and PRCC, we sought specifically to assess the concordance of WHO/ISUP grading on DP and GS. In so doing, we also determined the intraobserver and interobserver agreement for assignment of WHO/ISUP grade.

Our results show that overall the assessment of WHO/ISUP grade on DP is non-inferior to that on GS. The concordance of WHO/ISUP grading on DP and GS was 65 to $78 \%$ across the three pathologists, though it is 
Table 1 Summary of all WHO/ISUP grading for all three pathologists on DP and on GS read 1 and GS read 2. Cases 1-50=clear cell renal cell carcinoma. Case 51-60 = papillary renal cell carcinoma

\begin{tabular}{|c|c|c|c|c|c|c|c|c|c|c|}
\hline \multirow[t]{2}{*}{ CASE } & \multirow{2}{*}{$\begin{array}{l}\text { Nephrectomy (N) or partial } \\
\text { nephrectomy (PN), or biopsy (B) }\end{array}$} & \multicolumn{3}{|c|}{ PATHOLOGIST A } & \multicolumn{3}{|c|}{ PATHOLOGIST B } & \multicolumn{3}{|c|}{ PATHOLOGIST C } \\
\hline & & $\mathrm{DP}$ & GS1 & GS2 & DP & GS1 & GS2 & $\mathrm{DP}$ & GS1 & GS2 \\
\hline$\overline{1}$ & PN & 3 & 3 & 3 & 2 & 2 & 3 & 2 & 3 & 3 \\
\hline 2 & $\mathrm{~N}$ & 3 & 3 & 3 & 3 & 3 & 3 & 3 & 3 & 3 \\
\hline 3 & PN & 2 & 2 & 2 & 3 & 2 & 2 & 2 & 3 & 3 \\
\hline 4 & B & 4 & 3 & 4 & 4 & 4 & 4 & 4 & 4 & 4 \\
\hline 5 & $\mathrm{~N}$ & 4 & 4 & 3 & 4 & 4 & 4 & 4 & 4 & 4 \\
\hline 6 & $\mathrm{~N}$ & 3 & 3 & 3 & 3 & 2 & 3 & 2 & 3 & 3 \\
\hline 7 & $\mathrm{~N}$ & 3 & 3 & 3 & 2 & 3 & 2 & 2 & 3 & 3 \\
\hline 8 & B & 1 & 2 & 2 & 2 & 2 & 2 & 1 & 2 & 1 \\
\hline 9 & $\mathrm{~N}$ & 3 & 3 & 3 & 3 & 3 & 2 & 2 & 2 & 2 \\
\hline 10 & $\mathrm{~N}$ & 3 & 3 & 3 & 3 & 2 & 3 & 3 & 3 & 3 \\
\hline 11 & PN & 3 & 3 & 3 & 3 & 3 & 2 & 3 & 3 & 3 \\
\hline 12 & $\mathrm{~N}$ & 4 & 4 & 4 & 4 & 4 & 4 & 4 & 4 & 4 \\
\hline 13 & PN & 3 & 3 & 2 & 3 & 2 & 3 & 3 & 3 & 3 \\
\hline 14 & $\mathrm{~N}$ & 3 & 3 & 2 & 2 & 3 & 3 & 3 & 3 & 3 \\
\hline 15 & PN & 2 & 3 & 2 & 2 & 2 & 2 & 2 & 3 & 3 \\
\hline 16 & $\mathrm{~N}$ & 4 & 4 & 3 & 3 & 4 & 4 & 3 & 3 & 3 \\
\hline 17 & $\mathrm{~N}$ & 2 & 3 & 3 & 2 & 2 & 2 & 2 & 2 & 3 \\
\hline 18 & PN & 2 & 2 & 2 & 2 & 2 & 2 & 2 & 2 & 2 \\
\hline 19 & $\mathrm{~N}$ & 2 & 3 & 2 & 2 & 3 & 3 & 2 & 2 & 2 \\
\hline 20 & $\mathrm{~N}$ & 4 & 4 & 4 & 4 & 4 & 4 & 4 & 4 & 4 \\
\hline 21 & PN & 2 & 2 & 2 & 2 & 2 & 2 & 2 & 2 & 2 \\
\hline 22 & PN & 2 & 2 & 2 & 3 & 2 & 2 & 2 & 2 & 2 \\
\hline 23 & B & 1 & 1 & 2 & 2 & 2 & 2 & 1 & 1 & 1 \\
\hline 24 & $\mathrm{~N}$ & 3 & 3 & 3 & 3 & 3 & 3 & 3 & 3 & 2 \\
\hline 25 & B & 3 & 2 & 2 & 3 & 2 & 2 & 2 & 2 & 1 \\
\hline 26 & PN & 3 & 3 & 3 & 4 & 4 & 4 & 3 & 3 & 3 \\
\hline 27 & PN & 2 & 3 & 3 & 3 & 3 & 2 & 3 & 3 & 3 \\
\hline 28 & $\mathrm{~N}$ & 4 & 4 & 4 & 4 & 4 & 4 & 4 & 4 & 4 \\
\hline 29 & $\mathrm{~N}$ & 3 & 3 & 3 & 3 & 3 & 3 & 3 & 3 & 2 \\
\hline 30 & $\mathrm{~N}$ & 4 & 4 & 4 & 4 & 4 & 4 & 4 & 4 & 2 \\
\hline 31 & PN & 3 & 3 & 3 & 3 & 3 & 3 & 3 & 3 & 3 \\
\hline 32 & PN & 2 & 2 & 2 & 2 & 2 & 2 & 2 & 2 & 2 \\
\hline 33 & PN & 2 & 2 & 2 & 3 & 2 & 2 & 1 & 2 & 2 \\
\hline 34 & $\mathrm{~N}$ & 3 & 3 & 3 & 3 & 2 & 3 & 3 & 3 & 3 \\
\hline 35 & PN & 3 & 3 & 3 & 3 & 2 & 3 & 3 & 3 & 3 \\
\hline 36 & $\mathrm{~N}$ & 4 & 4 & 4 & 4 & 4 & 4 & 4 & 3 & 3 \\
\hline 37 & $\mathrm{~N}$ & 3 & 3 & 3 & 3 & 2 & 3 & 4 & 3 & 3 \\
\hline 38 & PN & 2 & 3 & 2 & 2 & 2 & 2 & 2 & 2 & 2 \\
\hline 39 & $\mathrm{~N}$ & 2 & 2 & 2 & 2 & 2 & 2 & 2 & 2 & 2 \\
\hline 40 & PN & 3 & 3 & 3 & 3 & 3 & 3 & 3 & 3 & 3 \\
\hline 41 & PN & 3 & 3 & 3 & 2 & 2 & 2 & 2 & 3 & 3 \\
\hline 42 & $\mathrm{~N}$ & 3 & 3 & 3 & 3 & 2 & 2 & 3 & 3 & 3 \\
\hline
\end{tabular}


Table 1 Summary of all WHO/ISUP grading for all three pathologists on DP and on GS read 1 and GS read 2. Cases 1-50=clear cell renal cell carcinoma. Case 51-60 = papillary renal cell carcinoma (Continued)

\begin{tabular}{|c|c|c|c|c|c|c|c|c|c|c|}
\hline \multirow[t]{2}{*}{ CASE } & \multirow{2}{*}{$\begin{array}{l}\text { Nephrectomy (N) or partial } \\
\text { nephrectomy (PN), or biopsy (B) }\end{array}$} & \multicolumn{3}{|l|}{ PATHOLOGIST A } & \multicolumn{3}{|l|}{ PATHOLOGIST B } & \multicolumn{3}{|l|}{ PATHOLOGIST C } \\
\hline & & DP & GS1 & GS2 & DP & GS1 & GS2 & DP & GS1 & GS2 \\
\hline 43 & PN & 3 & 3 & 3 & 3 & 2 & 2 & 3 & 3 & 3 \\
\hline 44 & PN & 3 & 3 & 3 & 3 & 3 & 3 & 3 & 3 & 3 \\
\hline 45 & PN & 3 & 3 & 3 & 3 & 3 & 3 & 3 & 3 & 3 \\
\hline 46 & $\mathrm{~N}$ & 2 & 3 & 3 & 2 & 3 & 2 & 3 & 3 & 3 \\
\hline 47 & B & 4 & 3 & 4 & 4 & 4 & 4 & 4 & 4 & 4 \\
\hline 48 & $\mathrm{~N}$ & 3 & 3 & 3 & 3 & 3 & 3 & 3 & 3 & 3 \\
\hline 49 & B & 3 & 3 & 3 & 4 & 4 & 3 & 4 & 4 & 4 \\
\hline 50 & PN & 3 & 3 & 3 & 3 & 3 & 3 & 3 & 3 & 3 \\
\hline 51 & B & 2 & 2 & 2 & 2 & 2 & 2 & 1 & 2 & 1 \\
\hline 52 & PN & 2 & 3 & 3 & 2 & 2 & 2 & 3 & 3 & 2 \\
\hline 53 & $\mathrm{~N}$ & 2 & 2 & 2 & 2 & 2 & 2 & 1 & 2 & 2 \\
\hline 54 & B & 2 & 2 & 1 & 2 & 2 & 2 & 1 & 1 & 1 \\
\hline 55 & PN & 3 & 3 & 3 & 3 & 2 & 2 & 3 & 3 & 3 \\
\hline 56 & $\mathrm{~N}$ & 3 & 2 & 2 & 2 & 2 & 2 & 1 & 3 & 2 \\
\hline 57 & N & 2 & 2 & 2 & 1 & 2 & 2 & 2 & 2 & 2 \\
\hline 58 & PN & 3 & 3 & 3 & 3 & 2 & 2 & 3 & 3 & 2 \\
\hline 59 & N & 2 & 3 & 2 & 2 & 2 & 2 & 2 & 3 & 2 \\
\hline 60 & PN & 3 & 3 & 3 & 3 & 2 & 2 & 3 & 3 & 3 \\
\hline
\end{tabular}

DP digital pathology, GS glass slides

noted that the individual kappa scores could be regarded only as 'moderate to substantial'. The concordance was slightly improved if the analysis was limited to CCRCC cases. Importantly the individual kappa agreement between DP and GS (read 1) and the two GS reads was almost identical for two of the pathologists $(=0.70$ and $0.70,=0.71$ and 0.74 respectively), and marginally different for the third pathologist ( $=0.57$ vs 0.73 ), which also suggests the non-inferiority of DP for WHO/ISUP grading.

Importantly, our results have demonstrated that there does not appear to be a tendency either way to over or undergrade either CCRCC or PRCC on DP compared with GS; 17 CCRCC grades (across all three pathologists, i.e. out of 180 grading events) being downgraded by one grade on glass review, and 20 upgraded by one grade, and 4 PRCC grades being downgraded by one grade on glass review, and 6 upgraded by one grade. A single PRCC grade was upgraded from 1 to 3 on GS review (one pathologist). This is reassuring given the significance of the tumour grade for prognostication and management planning, including for example, within the Leibovich scoring system [17]. However, we would advocate that in spite of the reassurance proffered by these results, that pathologists retain a low threshold for seeking further opinion when they are uncertain about assignment of grade as, particularly for CCRC $\mathrm{C}$, this can make a considerable difference to the risk group a patient falls into [17], and their subsequent management.

\begin{tabular}{|c|c|c|c|c|}
\hline Pathologist & \multicolumn{2}{|l|}{ All cases } & \multicolumn{2}{l|}{ CCRCC only } \\
\hline A & DP vs GS1 & GS1 vs GS2 & DP vs GS1 & GS1 vs GS2 \\
\hline B & 0.70 & 0.70 & 0.72 & 0.69 \\
\hline C & 0.57 & 0.73 & 0.58 & 0.69 \\
\hline & 0.71 & 0.74 & 0.75 & 0.81 \\
\hline
\end{tabular}

Fig. 1 Cohen's Kappa agreement for individual pathologists between DP and GS read 1 and for GS read 1 and GS read 2 


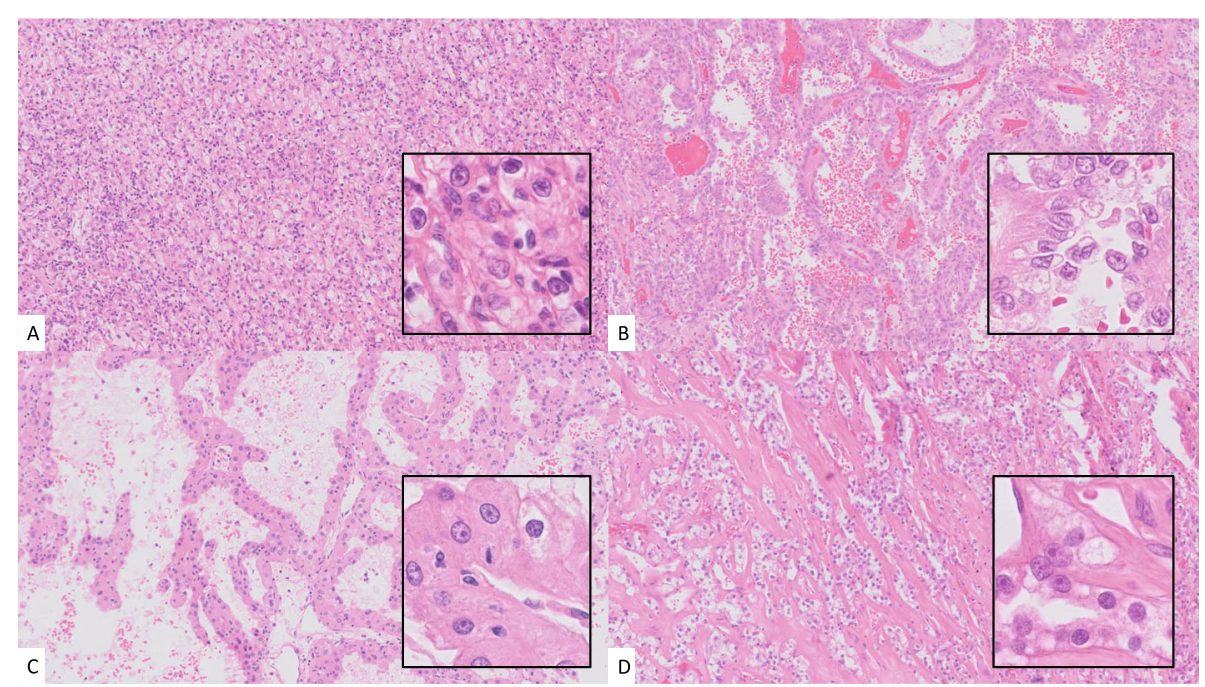

Fig. 2 (A) CCRCC (H\&E x10, inset H\&E x40) case where all three pathologists agreed on ISUP grading (grade 3) on both DP and GS1 review. (B) PRCC (H\&E x10, inset H\&E x40) case which was upgraded by one pathologist by two grades (ISUP grade 1 on DP to 3 on GS1 review), and downgraded by one pathologist (ISUP grade 3 to 2). (C) CCRCC (H\&E X10, inset H\&E X40) case which was downgraded from ISUP grade 3 on DP to 2 on GS1 review by one pathologist, upgraded from ISUP 2 to 3 by one pathologist, and graded 3 by a third pathologist on both DP and GS1 review. (D) CCRCC (H\&E X10, inset H\&E X40) case which was upgraded from ISUP grade 2 on DP to 3 on GS1 review by two pathologists, and graded as ISUP 3 by a third pathologist on both DP and GS1 review. CCRCC = clear cell renal cell carcinoma, PRCC = papillary renal cell carcinoma, DP = digital pathology, GS = glass slide, ISUP = International Society of Urological Pathology.

Whilst the intraobserver agreement between DP and GS is considered to be the most appropriate method to evidence whether DP performance is as reliable as conventional microscopy $[2,18]$, we sought also to determine the overall interobserver agreement on WHO/ ISUP grade. Across all cases the interobserver kappa scores of agreement on grade were 0.58 on DP, 0.45 on GS read 1, and 0.49 for GS read 2. When the analysis was restricted to CCRCC, the interobserver kappa agreement was minimally different; 0.62 on DP, 0.50 on GS read 1, 0.48 on GS read 2. These figures suggest marginal greater agreement of interobserver kappa score for DP over GS, although this is a small study.

Given that WHO/ISUP grading conveys important prognostic information as to the likely behaviour of CCRCC or PRCC, influencing the patient follow-up protocol and potentially clinical trial entry, it is noteworthy that there is a lack of published literature on the reproducibility of the WHO/ISUP grade, although it is commented upon by some authors that there is recognised interobserver variability [21]. To the best of the authors' knowledge, this is the first study formally to report on reproducibility of WHO/ISUP grade, either between pathologists or on separate sittings for the same pathologist.

Prior to the ISUP grading system the issues of reproducibility of the Fuhrman grading system were recognised; for example, one study reported only a low to moderate level of interobserver agreement on Fuhrman grading of RCC (mean value 0.22) [22]. These difficulties in reproducibility were felt in part to be due to the multifactorial nature of this grading system, which included nuclear diameter, nuclear shape, and nucleolar prominence [23]. This led in part to the proposal of a new system based upon nucleolar grading [23], and this subsequent 'ISUP grading system' [16] was then designated with minor modifications as the WHO/ISUP grading system, [15]. However, the reproducibility of this new grading system is not specifically mentioned or indeed assessed in papers validating it [24-27].

We have shown in this study that the intraobserver reproducibility of WHO/ISUP grading of CCRCC and PRCC by three specialist urological pathologists can be considered substantial, and consistently so when comparing assessment on glass slides. Interobserver reproducibility is however only moderate, although it is greater than the reported reproducibility of Fuhrman grade [22]. There does appear to be slightly greater interobserver reproducibility of grade when assessed on DP in comparison to GS, something that has in fact been previously postulated [21], however this is a small study. This observation warrants further study and potentially lends itself to automated assessment using artificial intelligence (AI), which may further improve consistency of grading in future. Indeed, a recently published study reported the development of a deep learning model to determine the grade of RCC, and suggested that the categorical accuracy for predicting tumour grade (Fuhrman) using this 
Table 2 Summary of major digital pathology validation studies which include urological specimens

\begin{tabular}{|c|c|c|c|c|c|}
\hline AUTHOR & $\begin{array}{l}\text { SCANNING } \\
\text { SYSTEM } \\
\text { EVALUATED }\end{array}$ & $\begin{array}{l}\text { SCANNING } \\
\text { MAGNIFICATION }\end{array}$ & STUDY METHODOLOGY & $\begin{array}{l}\text { UROLOGICAL } \\
\text { CASES INCLUDED } \\
\text { IN STUDY }\end{array}$ & $\begin{array}{l}\text { AREAS OF DISCORDANCE } \\
\text { BETWEEN GLASS SLIDE (GS) } \\
\text { READ AND DIGITAL } \\
\text { PATHOLOGY (DP) READ FOR } \\
\text { PURPOSE OF STUDY } \\
\text { (EXCLUDING ORIGINAL } \\
\text { DIAGNOSIS OR ADJUDICATED } \\
\text { DIAGNOSIS WHERE GIVEN) }\end{array}$ \\
\hline $\begin{array}{l}\text { Campbell } 2012 \\
\text { [5] }\end{array}$ & iScan $^{\circledast}$ & $\times 20$ & $\begin{array}{l}\text { Single centre study } \\
2 \text { pathologists } \\
\text { Digital diagnosis compared with } \\
\text { original diagnoses (no washout } \\
\text { period as the original glass slide } \\
\text { diagnosis was the comparator), } \\
\text { consensus diagnosis for } \\
\text { discrepant cases }\end{array}$ & $\begin{array}{l}N=6 \\
\text { Type not specified }\end{array}$ & $\begin{array}{l}\text { Prostate biopsy ( } 1 \text { case) - benign } \\
\text { (GS) vs. ASAP (DP) } \\
\text { Bladder specimen (type not } \\
\text { specified, } 1 \text { case) - suggestive of } \\
\text { polypoid cystitis (GS) vs. PUNLMP } \\
\text { (DP) }\end{array}$ \\
\hline Bauer 2013 [3] & $\begin{array}{l}\text { Aperio }{ }^{\oplus} \text { ScanScope } \\
\text { XT }\end{array}$ & $\times 20$ & $\begin{array}{l}\text { Multicentre study } \\
2 \text { pathologists } \\
\text { Glass diagnosis followed by } \\
\text { washout period of } 1 \text { year, then } \\
\text { either digital or GS review, } \\
\text { consensus diagnosis for } \\
\text { discrepant cases }\end{array}$ & Type not specified & $\begin{array}{l}\text { Prostate specimens (type not } \\
\text { specified, } 6 \text { cases) - Gleason } \\
\text { grading ( } 33 \text { cases), benign (GS) vs. } \\
\text { HG PIN (DP), PIN (GS) vs. benign } \\
\text { (DP) }\end{array}$ \\
\hline $\begin{array}{l}\text { Al-Janabi } 2014 \\
\text { [19] }\end{array}$ & Not specified & $\times 20$ & $\begin{array}{l}\text { Single centre study } \\
2 \text { pathologists } \\
\text { Digital diagnosis compared with } \\
\text { original diagnoses (each } \\
\text { pathologist reviewed only the GS } \\
\text { cases they originally diagnosed), } \\
\text { washout period minimum } 6 \\
\text { months. } \\
\text { The original glass slide diagnosis } \\
\text { was the comparator, consensus } \\
\text { diagnosis for discrepant cases }\end{array}$ & $\begin{array}{l}N=100 \\
\text { Urinary system } \\
\text { only } \\
\text { Kidney }=50 \text { ( } 48 \\
\text { cases were medical } \\
\text { renal disease } \\
\text { diagnoses, } 2 \\
\text { surgical diagnoses) } \\
\text { Bladder }=43 \\
\text { Ureter }=1 \\
\text { Urethra }=6\end{array}$ & $\begin{array}{l}\text { Excluding the medical renal cases } \\
\text { Bladder specimens ( } 5 \text { cases) - } \\
\text { Grade } 3 \text { PUC, non-invasive (GS) } \\
\text { vs. grade } 3 \text { PUC with lamina pro- } \\
\text { pria invasion (DP), benign no ab- } \\
\text { normality (GS) vs. chronic } \\
\text { inflammation (DP), grade } 3 \text { PUC, } \\
\text { suspicious for invasion (GS) vs. } \\
\text { grade } 3 \text { PUC with lamina propria } \\
\text { invasion and CIS (DP), \& } 2 \text { cases } \\
\text { with minor descriptive discrep- } \\
\text { ancy only }\end{array}$ \\
\hline Snead 2016 [8] & Omnyx $x^{\oplus}$ VL4 & $x 40$ & $\begin{array}{l}\text { Single centre study } \\
17 \text { pathologists } \\
\text { Glass slide diagnosis, followed by } \\
\text { washout period of } 21 \text { days, } \\
\text { before digital read ( } 33 \% \text { cases } \\
\text { reported on GS and digital by the } \\
\text { same pathologist, and } 66 \% \text { by } \\
\text { two different pathologists), } \\
\text { consensus diagnosis for } \\
\text { discrepant cases }\end{array}$ & $\begin{array}{l}N=242 \\
\text { Type not specified }\end{array}$ & $\begin{array}{l}\text { Penile biopsy with HPV changes } \\
\text { and atypia (GS) vs. PeIN (DP) } \\
\text { Prostate biopsies ( } 2 \text { cases) - } \\
\text { Gleason grading (pattern } 4 \text { vs. 3), } \\
\text { suspicious for malignancy (GS) vs. } \\
\text { benign (DP) } \\
\text { Urothelial biopsies (3 cases) - } \\
\text { Urothelial carcinoma grade } 1 \text { LG } \\
\text { (GS) vs. grade } 2 \text { HG (DP), } \\
\text { urothelial carcinoma with no CIS } \\
\text { (GS) vs. urothelial carcinoma with } \\
\text { CIS (DP), non-invasive urothelial } \\
\text { carcinoma (GS) vs. urothelial car- } \\
\text { cinoma with early invasion (DP) }\end{array}$ \\
\hline Tabata 2017 [9] & $\begin{array}{l}\text { PhilipsIntelliSite } \\
\text { Ultrafast scanner } \\
\text { Leica Biosystems }^{\circledast} \\
\text { Aperio }{ }^{\circledR} \text { AT2 } \\
\text { scanner } \\
\text { Hamamatsu } \\
\text { Nanozoomer }{ }^{\circledast} 2.0- \\
\text { HT C9600-13 } \\
\text { Hamamatsu } \\
\text { NanoZoomer }{ }^{\circledast} 2.0- \\
\text { RS C10730-13 } \\
\text { CLARO FINO }\end{array}$ & $\begin{array}{l}\text { Variable, } \times 20 \text { and } \\
\times 40\end{array}$ & $\begin{array}{l}\text { Multicentre study } \\
9 \text { pathologists } \\
\text { Each pathologist carried out } \\
\text { digital and glass slide reads on } \\
\text { each case, washout period } \\
\text { minimum of } 14 \text { days, consensus } \\
\text { diagnosis for discrepant cases }\end{array}$ & $N=66$ & $\begin{array}{l}\text { Prostate specimen (type not } \\
\text { specified, } 1 \text { case) - benign (GS) } \\
\text { vs. atypical glands (DP) } \\
\text { Genitourinary organ (not } \\
\text { specified, } 1 \text { case) - erosive } \\
\text { mucosa without malignancy (GS) } \\
\text { vs. erosive mucosa possible for } \\
\text { malignancy (DP) }\end{array}$ \\
\hline $\begin{array}{l}\text { Mukhopadhyay } \\
2018 \text { [7] }\end{array}$ & $\begin{array}{l}\text { Philips IntelliSite } \\
\text { Pathology Solution }\end{array}$ & Not specified & $\begin{array}{l}\text { Multicentre study } \\
16 \text { pathologists } \\
\text { Each pathologist carried out } \\
\text { digital and glass slide reads on } \\
\text { each case, washout period }\end{array}$ & $\begin{array}{l}N=448 \\
\text { Urinary bladder }= \\
99 \\
\text { Prostate }=299 \\
\text { Kidney, }\end{array}$ & $\begin{array}{l}\text { Kidney, neoplastic (2 cases) - } \\
\text { papillary RCC (GS) vs. metanephric } \\
\text { adenoma (DP), HG papillary } \\
\text { urothelial carcinoma (GS) vs. LG } \\
\text { urothelial carcinoma (DP) }\end{array}$ \\
\hline
\end{tabular}


Table 2 Summary of major digital pathology validation studies which include urological specimens (Continued)

\begin{tabular}{|c|c|c|c|c|c|}
\hline AUTHOR & $\begin{array}{l}\text { SCANNING } \\
\text { SYSTEM } \\
\text { EVALUATED }\end{array}$ & $\begin{array}{l}\text { SCANNING } \\
\text { MAGNIFICATION }\end{array}$ & STUDY METHODOLOGY & $\begin{array}{l}\text { UROLOGICAL } \\
\text { CASES INCLUDED } \\
\text { IN STUDY }\end{array}$ & $\begin{array}{l}\text { AREAS OF DISCORDANCE } \\
\text { BETWEEN GLASS SLIDE (GS) } \\
\text { READ AND DIGITAL } \\
\text { PATHOLOGY (DP) READ FOR } \\
\text { PURPOSE OF STUDY } \\
\text { (EXCLUDING ORIGINAL } \\
\text { DIAGNOSIS OR ADJUDICATED } \\
\text { DIAGNOSIS WHERE GIVEN) }\end{array}$ \\
\hline
\end{tabular}

$\begin{array}{ll}\text { Vodovnik } 2018 & \text { Aperio }^{\circledast} \\ \text { [13] } & \text { ScanScope }^{\oplus} \text { AT } \\ & \text { Turbo }\end{array}$

Borowsky 2020 Leica Biosystems ${ }^{\oplus}$

[4] Aperio $^{\oplus}$ AT2 DX system
Hanna $2020 \quad$ Leica Biosystems ${ }^{\oplus} \quad$ x40

[11] Aperio ${ }^{\oplus}$ GT40 $\times 20$

$\times 20$ minimum of 16 days, reference standard = original GS diagnosis, with adjudication for discrepant cases neoplastic $=50$

Urinary bladder (not otherwise specified) (18 cases) - cystitis with reactive atypia (GS) vs. HG CIS

(DP), HG non-invasive PUC (GS) vs. HG PUC with lamina propria invasion (DP), HG PUC without invasion (GS) vs. LG PUC noninvasive (DP), LG PUC noninvasive (GS) vs. LG PUC with invasion (DP), cystitis with hyperplasia (GS) vs. flat HG dysplasia (DP), HG urothelial carcinoma (GS) vs. fibrosis, benign (DP), tissue highly suspicious for invasive SCC (GS) vs. mildly atypical squamous epithelium, favour squamous metaplasia (DP), HG urothelial carcinoma invading through bladder wall into perivesical soft tissue (GS) vs. benign (DP), cystitis with mucosal ulceration with reactive atypia (GS) vs. myoinvasive HG urothelial carcinoma (DP), cystitis with granulomatous features and reactive atypia (GS) vs. myoinvasive HG urothelial carcinoma (DP), CIS (GS) vs. cystitis (DP), HG PUC non-invasive (GS) vs. HG PUC with lamina propria invasion (DP), cystitis with reactive atypia (GS) vs, CIS (DP), CIS (GS) vs. HG urothelial carcinoma with lamina propria invasion (DP), atypical urothelium (GS) vs. benign (DP), CIS (GS) vs. inflammation (DP), CIS (GS) vs. inflammation (DP), CIS (GS) vs. inflammation (DP)

Single centre study $\quad N=75$

1 pathologist

Digital diagnosis compared with original diagnosis (the pathologist had reported the cases on both GS and DP), washout period 6 months.

Multicentre study

19 pathologists

Each pathologist carried out digital and glass slide reads on each case, washout period minimum of 31 days, reference standard = original GS diagnosis, with adjudication for discrepant cases

Single centre study

12 pathologists (2 reporting GU cases)

Each pathologist carried out digital and glass slide reads on each case, the digital read was done remotely via a virtual

Prostatic adenocarcinoma grading Gleason $9(5+4)$ (GS) vs. Gleason $9(4+5)(\mathrm{DP})$

UC HG grade 2-3 (GS) vs. UC HG grade 2 (DP)
$N=447$

Urinary bladder $=$ 100

Prostate $=300$

Kidney,

neoplastic $=47$

718 slides $=108$ cases in total across specialties, and for GU the

following specimens; Prostate $=151$
Not specified, although comment that urinary bladder biopsies showed the highest major discrepancy rate

No major or minor discordances 
Table 2 Summary of major digital pathology validation studies which include urological specimens (Continued)

\begin{tabular}{|c|c|c|c|c|c|}
\hline AUTHOR & $\begin{array}{l}\text { SCANNING } \\
\text { SYSTEM } \\
\text { EVALUATED }\end{array}$ & $\begin{array}{l}\text { SCANNING } \\
\text { MAGNIFICATION }\end{array}$ & STUDY METHODOLOGY & $\begin{array}{l}\text { UROLOGICAL } \\
\text { CASES INCLUDED } \\
\text { IN STUDY }\end{array}$ & $\begin{array}{l}\text { AREAS OF DISCORDANCE } \\
\text { BETWEEN GLASS SLIDE (GS) } \\
\text { READ AND DIGITAL } \\
\text { PATHOLOGY (DP) READ FOR } \\
\text { PURPOSE OF STUDY } \\
\text { (EXCLUDING ORIGINAL } \\
\text { DIAGNOSIS OR ADJUDICATED } \\
\text { DIAGNOSIS WHERE GIVEN) }\end{array}$ \\
\hline & & & $\begin{array}{l}\text { private network (VPN), and the GS } \\
\text { read was done on site in the } \\
\text { hospital department with a mean } \\
\text { interval of } 2 \text { days. Reference } \\
\text { standard = GS diagnosis with } \\
\text { adjudication for discordant cases. }\end{array}$ & $\begin{array}{l}\text { Bladder }=28 \\
\text { Lymph nodes }=10 \\
\text { Kidney }=9 \\
\text { Urethra }=6 \\
\text { Testis }=3 \\
\text { Ureter }=1 \\
\text { Adrenal }=1 \\
\text { Other }=10\end{array}$ & \\
\hline Rao 2021 [12] & Ventana ${ }^{\circledast}$ DP200 & $\begin{array}{l}\times 20(\times 40 \\
\text { scanning } \\
\text { available on } \\
\text { request) }\end{array}$ & $\begin{array}{l}\text { Single centre study } \\
18 \text { pathologists } \\
\text { Study looked at concordance } \\
\text { between digital sign out of cases } \\
\text { remotely (from home) with } \\
\text { blinded re-review of cases after a } \\
\text { minimum } 2 \text { week interval. Con- } \\
\text { cordance adjudicated by a referee } \\
\text { pathologist not participating in } \\
\text { the sign out study. Blind consen- } \\
\text { sus diagnosis established for dis- } \\
\text { cordant diagnoses. }\end{array}$ & $\begin{array}{l}N=25 \text { ( } 1 \text { of which } \\
\text { was deferred to } \\
\text { glass) } \\
47 \text { parts, } 74 \text { slides; } \\
\text { Urinary bladder, } \\
\text { ureteric orifice }=24 \\
\text { Kidney }=5 \\
\text { Penis }=2 \\
\text { Prostate }=12 \\
\text { lliac fossa }=1 \\
\text { Lung }=1 \\
\text { Endometrium }=1 \\
\text { Rectum }=1\end{array}$ & $\begin{array}{l}\text { Urinary bladder (1 case, TURBT) } \\
\text { HG PUC T1 (GS) vs. HG PUC Ta } \\
\text { (DP) }\end{array}$ \\
\hline
\end{tabular}

GS glass slides, DP digital pathology, ASAP atypical small acinar proliferation, PUNLMP papillary urothelial neoplasm of low malignant potential, PIN prostatic intraepithelial neoplasia, PUC papillary urothelial carcinoma, CIS carcinoma in situ, HPV human papilloma virus, PeIN penile intraepithelial neoplasia, LG WHO 2004 low grade, HG WHO 2004 high grade, RCC renal cell carcinoma, SCC squamous cell carcinoma, GU genitourinary, TURBT transurethral resection of bladder tumour

model was $98.4 \%$ [28]. Such tools may be of value in improving grading accuracy in future.

\section{Conclusions}

We have demonstrated in this validation study that DP is non-inferior to GS in terms of assessment of WHO/ISUP grading in CCRCC or PRCC. However assessment of nuclear detail is a recognised area of potential challenge in assessment in DP and, given that WHO/ISUP grading relies upon nucleolar features pathologists should remain aware that this is a potential pitfall.

The reproducibility of WHO/ISUP grade is of direct clinical relevance, and whilst we have demonstrated that this appears to be moderate to substantial at both intraobserver and interobserver level, it would seem that DP may potentially facilitate greater consistency in grading. AI tools to automate grading of RCC may offer a further means to improve reproducibility.

\section{Abbreviations}

WHO: World Health Organisation; ISUP: International Society of Urological Pathology; RCC: Renal cell carcinoma; CCRCC: Clear cell renal cell carcinoma; PRCC: Papillary renal cell carcinoma; DP: Digital pathology; GS: Glass slide; FRCPath: Fellowship of the Royal College of Pathologists; Al: Artificial intelligence

\section{Acknowledgements}

We acknowledge the work of the Digital Pathology Steering Group at Oxford University Hospitals NHS Foundation Trust in overseeing the transition to digital pathology within the department.

\section{Authors' contributions}

$L B, R C, C V$ contributed equally to the study design and all participated in the histological analysis of the cases. LB was the major contributor to the writing of the manuscript. All authors read and approved the final manuscript.

\section{Funding}

This paper is supported by the PathLAKE Centre of Excellence for digital pathology and Al which is funded from the Data to Early Diagnosis and Precision Medicine strand of the government's Industrial Strategy Challenge Fund, managed and delivered by Innovate UK on behalf of UK Research and Innovation (UKRI). Views expressed are those of the authors and not necessarily those of the PathLAKE Consortium members, the NHS, Innovate UK or UKRI.

PathLAKE funding reference: 104689 / Application number: 18181

$\mathrm{CV}$ and $\mathrm{LB}$ are part funded by the National Institute for Health Research (NIHR) Oxford Biomedical Research Centre (BRC). The views expressed are those of the author(s) and not necessarily those of the NHS, the NIHR or the Department of Health. Funding is via the Molecular Diagnostics Theme.

Availability of data and materials

All data generated or analysed during this study are included in this published article.

\section{Declarations}

Ethics approval and consent to participate

This study was carried out as a registered clinical audit and ethics approval and consent was not required. 


\section{Consent for publication}

Not applicable

\section{Competing interests}

Oxford is part of the PathLAKE digital pathology consortium. PathLAKE is one of the UK Government's 5 Al Centres of Excellence and has received in kind industry investment from Philips for digital pathology equipment, software and other services. In this context we have also received research support from InnovateUK for the PathLAKE consortium project - grant ref:File Ref: 104689/Application number: 18181.

CV is a joint PI for Oxford PathLAKE.

\section{Author details}

${ }^{1}$ Department of Cellular Pathology, Oxford University Hospitals NHS Trust, John Radcliffe Hospital, Headley Way, OX3 9DU Oxford, UK. ${ }^{2}$ NIHR Oxford Biomedical Research Centre, Oxford University Hospitals NHS Foundation Trust, Oxford, Oxfordshire, UK. ${ }^{3}$ Nuffield Department of Surgical Sciences, University of Oxford, John Radcliffe Hospital, OX3 9DU Oxford, UK.

\section{Received: 1 February 2021 Accepted: 12 July 2021}

\section{Published online: 21 August 2021}

\section{References}

1. Royal College of Pathologists. Best practice recommendations for digital pathology. 2018. Available: https://www. rcpath. org/ resourceLibrary/ bestpractice recommendations- for- implementing- digital- pathology- pdf. Accessed 31 Jan 2021.

2. Araújo ALD, Arboleda LPA, Palmier NR, Fonsêca JM, de Pauli Paglioni M, Gomes-Silva W, et al. The performance of digital microscopy for primary diagnosis in human pathology: a systematic review. Virchows Arch. 2019; 474(3):269-87. doi:https://doi.org/10.1007/s00428-018-02519-z.

3. Bauer TW, Schoenfield L, Slaw RJ, Yerian L, Sun Z, Henricks WH. Validation of whole slide imaging for primary diagnosis in surgical pathology. Arch Pathol Lab Med. 2013;137(4):518-24. doi:https://doi.org/10.5858/arpa.20110678-OA.

4. Borowsky AD, Glassy EF, Wallace WD, Kallichanda NS, Behling CA, Miller DV, et al. Digital Whole Slide Imaging Compared With Light Microscopy for Primary Diagnosis in Surgical Pathology. Arch Pathol Lab Med. 2020;144(10): 1245-53. https://doi.org/10.5858/arpa.2019-0569-OA.

5. Campbell WS, Lele SM, West WW, Lazenby AJ, Smith LM, Hinrichs SH, Concordance between whole-slide imaging and light microscopy for routine surgical pathology. Hum Pathol. 2012;43(10):1739-44. doi:https://doi. org/10.1016/j.humpath.2011.12.023.

6. Goacher E, Randell R, Williams B, Treanor D. The Diagnostic Concordance of Whole Slide Imaging and Light Microscopy: A Systematic Review. Arch Pathol Lab Med. 2017;141(1):151-61. doi:https://doi.org/10.5858/arpa.20160025-RA.

7. Mukhopadhyay S, Feldman MD, Abels E, Ashfaq R, Beltaifa S, Cacciabeve NG et al. Whole Slide Imaging Versus Microscopy for Primary Diagnosis in Surgical Pathology: A Multicenter Blinded Randomized Noninferiority Study of 1992 Cases (Pivotal Study). Am J Surg Pathol. 2018;42(1):39-52. doi: https://doi.org/10.1097/PAS.0000000000000948.

8. Snead DR, Tsang YW, Meskiri A, Kimani PK, Crossman R, Rajpoot NM, et al. Validation of digital pathology imaging for primary histopathological diagnosis. Histopathology. 2016;68(7):1063-72. doi:https://doi.org/10.1111/ his. 12879

9. Tabata K, Mori I, Sasaki T, Itoh T, Shiraishi T, Yoshimi N, et al. Whole-slide imaging at primary pathological diagnosis: Validation of whole-slide imaging-based primary pathological diagnosis at twelve Japanese academic institutes. Pathol Int. 2017 Nov;67(11):547-54.

10. Williams BJ, DaCosta P, Goacher E, Treanor D. A Systematic Analysis of Discordant Diagnoses in Digital Pathology Compared With Light Microscopy. Arch Pathol Lab Med. 2017;141(12):1712-8. doi:https://doi.org/1 0.5858/arpa.2016-0494-OA.

11. Hanna MG, Reuter VE, Ardon O, Kim D, Sirintrapun SJ, Schüffler PJ, et al. Validation of a digital pathology system including remote review during the COVID-19 pandemic. Mod Pathol. 2020 Nov;33(11):2115-27. doi:https://doi. org/10.1038/s41379-020-0601-5. Epub 2020 Jun 22. PMID: 32572154; PMCID: PMC7306935.

12. Rao V, Kumar R, Rajaganesan S, Rane S, Deshpande G, Yadav S, et al. Remote reporting from home for primary diagnosis in surgical pathology: $A$ tertiary oncology center experience during the COVID-19 pandemic. J Pathol Inform. 2021:12:3.

13. Vodovnik A, Aghdam MR. Complete routine remote digital pathology services. J Pathol Inform. 2018:9:36.

14. Williams BJ, Treanor D. Practical guide to training and validation for primary diagnosis with digital pathology. J Clin Pathol. 2020 Jul;73(7):418-22.

15. Humphrey PA, Moch H, Reuter VE, Ulbright TM, editors. World Health Organisation (WHO) Classification of tumours. Pathology and genetics of the urinary system and male genital organs. Lyon: IARC Press; 2016.

16. Delahunt B, Cheville JC, Martignoni G, Humphrey PA, Magi-Galluzzi C, McKenney J, et al. The International Society of Urological Pathology (ISUP) grading system for renal cell carcinoma and other prognostic factors. Am J Surg Pathol. 2013;37:1490-504

17. Leibovich BC, Blute ML, Cheville JC, Lohse CM, Frank I, Kwon ED, et al. Prediction of progression after radical nephrectomy for patients with clear cell renal cell carcinoma: a stratification tool for prospective clinical trials. Cancer. 2003;97:1663-71.

18. Pantanowitz $L$, Sinard JH, Henricks WH, Fatheree LA, Carter AB, Contis L, et al. College of American Pathologists Pathology and Laboratory Quality Center Validating whole slide imaging for diagnostic purposes in pathology: guideline from the College of American Pathologists Pathology and Laboratory Quality Center. Arch Pathol Lab Med. 2013;137:1710-22.

19. Azam AS, Miligy IM, Kimani PK, Maqbool H, Hewitt K, Rajpoot NM, et al. Diagnostic concordance and discordance in digital pathology: a systematic review and meta-analysis. J Clin Pathol. 2020 Sep 15:jclinpath-2020-206764. doi: https://doi.org/10.1136/jclinpath-2020-206764. Epub ahead of print. PMID: 32934103

20. Al-Janabi S, Huisman A, Jonges GN, Ten Kate FJ, Goldschmeding R, van Diest PJ. Whole slide images for primary diagnostics of urinary system pathology: a feasibility study. J Renal Inj Prev. 2014;3(4):91-6. doi:https://doi. org/10.12861/jrip.2014.26. Published 2014 Dec 1.

21. Warren AY, Harrison D. WHO/ISUP classification, grading and pathological staging of renal cell carcinoma: standards and controversies. World J Urol. 2018;36:1913-26.

22. Lang $\mathrm{H}$, Lindner $\mathrm{V}$, de Fromont $\mathrm{M}$, Molinié $\mathrm{V}$, Letourneux $\mathrm{H}$, Meyer $\mathrm{N}$, et al. Multicenter determination of optimal interobserver agreement using the Fuhrman grading system for renal cell carcinoma: Assessment of 241 patients with > 15-year follow-up. Cancer. 2005;103(3):625-9.

23. Delahunt B, Sika-Paotonu D, Bethwaite PB, William Jordan T, Magi-Galluzzi C, Zhou $M$, et al. Grading of clear cell renal cell carcinoma should be based on nucleolar prominence. Am J Surg Pathol. 2011;35:1134-9.

24. Cornejo KM, Dong F, Zhou AG, Wu CL, Young RH, Braaten K, et al. Papillary renal cell carcinoma: correlation of tumor grade and histologic characteristics with clinical outcome. Hum Pathol. 2015:46(10):1411-7. doi: https://doi.org/10.1016/j.humpath.2015.07.001

25. Khor LY, Dhakal HP, Jia X, Reynolds JP, McKenney JK, Rini Bl, et al. Tumor Necrosis Adds Prognostically Significant Information to Grade in Clear Cell Renal Cell Carcinoma: A Study of 842 Consecutive Cases From a Single Institution. Am J Surg Pathol. 2016;40(9):1224-31. doi:https://doi.org/10.1 097/PAS.0000000000000690

26. Dagher J, Delahunt B, Rioux-Leclercq N, Egevad L, Srigley JR, Coughlin G, et al. Clear cell renal cell carcinoma: validation of World Health Organization/International Society of Urological Pathology grading. Histopathology. 2017;71:918-25.

27. Kim H, Inomoto $\mathrm{C}$, Uchida $\mathrm{T}$, Furuya $\mathrm{H}$, Komiyama $\mathrm{T}$, Kajiwara $\mathrm{H}$, et al. Verification of the International Society of Urological Pathology recommendations in Japanese patients with clear cell renal cell carcinoma. Int J Oncol. 2017;52:1139-48.

28. Fenstermaker M, Tomlins SA, Singh K, Wiens J, Morgan TM. Development and Validation of a Deep-learning Model to Assist With Renal Cell Carcinoma Histopathologic Interpretation. Urology. 2020;144:152-7.

\section{Publisher's Note}

Springer Nature remains neutral with regard to jurisdictional claims in published maps and institutional affiliations. 